\title{
TRPV6 wt Allele
}

National Cancer Institute

\section{Source}

National Cancer Institute. TRPV6 wt Allele. NCI Thesaurus. Code C94617.

Human TRPV6 wild-type allele is located in the vicinity of 7q34 and is approximately $15 \mathrm{~kb}$ in length. This allele, which encodes transient receptor potential cation channel subfamily $\checkmark$ member 6 protein, plays a role in calcium transport, muscle contraction, neurotransmission and signal transduction. 